\title{
INTERACTION OF NOVEL LUBRICANT ADDITIVES BASED ON MOS, NANOTUBES WITH NON-FERROUS TRIBOLOGICAL MATERIALS
}

\author{
ODDZIALYWANIA NOWOCZESNYCH DODATKÓW SMARNOŚCIOWYCH \\ W FORMIE NANORUREK MOS, W OLEJU Z NIEŻELAZNYMI \\ POWIERZCHNIAMI TRĄCYMI
}

\begin{abstract}
Key words:
Nanoparticles, $\mathrm{MoS}_{2}$ nanotubes, Additives, Tribofilm, Friction, Wear.

Abstract

$\mathrm{MoS}_{2}$ nanotubes (NTs) are novel lubricant additives reducing friction and wear of mechanical components made of steel. Nowadays, non-ferrous surfaces are becoming more widely used, mainly as multifunctional coatings working in configuration with a steel pair. As a consequence, the purpose of this work is to reveal the interaction mechanism of nanoparticles with coated elements in lubricated contacts that are essential in future lubrication technologies. The tribological properties were investigated using a reciprocating sliding testing machine in a steel-ball-on-coated-disc configuration. For tribological studies, two commercially available coatings were selected: $\mathrm{WC} / \mathrm{C}$ and DLC coating. Frictional results show only slight improvement for lubricant blends containing $\mathrm{MoS}_{2}$ nanotubes with selected coatings, and wear tracks are surprisingly very extensive when compare to oils with additives. Generally, the presence of coating in any tribological test configurations diminish the effectiveness of $\mathrm{MoS}_{2}$ NTs when compare to steel/steel contact. Chemical analytics show that interaction mechanisms of the nanotubes and surface changes, depending on the coating material, have the ability to form a chemically derived tribofilm.
\end{abstract}

Słowa kluczowe:

Streszczenie: naonocząsteczki, nanorurki $\mathrm{MoS}_{2}$, dodatki uszlachetniające, tribo-chemiczna warstwa graniczna, tarcie, zużycie.

Nanorurki $\mathrm{MoS}_{2}$ są innowacyjnym dodatkiem do środków smarowych redukującym tarcie oraz zużycie stalowych elementów maszyn. Mechanizm ich działania w skojarzeniach elementów stalowych jest stosunkowo dobrze poznany i opisany. Obecnie coraz częściej na elementy maszyn stosowane są materiały nieżelazne, w tym niskotarciowe cienkie powłoki przeciwużyciowe. Brak obecności tlenków żelaza na powierzchniach trących determinuje zmianę charakteru oddziaływania nanocząsek z powierzchnią. Celem pracy jest opis oddziaływania środków smarowych $\mathrm{z}$ dodatkiem nanocząsteczek $\mathrm{MoS}_{2} \mathrm{w}$ skojarzeniach tribologicznych z powierzchniami elementów pokrytych powłokami typu DLC. Badania tribologiczne zostały zrealizowane z wykorzystaniem stanowiska SRV pracującego w warunkach ruchu oscylacyjnego, w którym węzeł tarcia stanowi stalowa kulka oraz tarcza pokryta powłoką niskotarciową. W badaniach stosowano powłoki typu WC/C i DLC. Stwierdzono, że zastosowanie niskotarciowych powłok na tarczach zmniejszyło efektywność działania nanorurek $\mathrm{MoS}_{2}$ w porównaniu ze skojarzeniem elementów stalowych bez powłoki. Odnotowano nieznaczną poprawę współczynnika tarcia dla skojarzeń smarowanych olejem zawierających nanorurki $\mathrm{MoS}_{2}$, jednakże zużycie elementów trących było znacznie większe niż uzyskiwane dla olejów bez dodatku nanorurek. Analiza chemiczna wykazała, że mechanizmy oddziaływania nanorurek i materiału powierzchni tarcia zmieniają się w zależności od materiału elementów trących, biorącego udział tworzeniu tribochemicznej warstwy granicznej.

\footnotetext{
* Institute for Sustainable Technologies - National Research Institute, 26-600 Radom, Poland, ul. Pułaskiego 6/10, e-mail: agnieszka.tomala@itee.radom.pl.

** AC2T research GmbH, 2700 Wiener Neustadt, Austria.
} 


\section{INTRODUCTION}

The stringent requirements from environmental legislations on reducing harmful elements are constantly forcing lubricant manufacturers to produce and implement greener additives. In the same way, equipment manufacturers are encourage to develop and implement novel materials in machine elements contacts with better mechanical, wear, and frictional properties. Some potential materials that are considered to hold great promise for such objectives and are of paramount interest in this research work are diamondlike carbon (DLC) coatings [L. 1, 2]. However, a major challenge involved in using these materials is ensuring satisfactory tribological performance with existing lubricant additives. This is because the existing lubricant additives (e.g., AW/EP, friction modifiers, detergents, dispersants, etc.) were designed to work with ferrous surfaces (e.g., steel on steel) and no adequate confidence exists on whether these additives can work and effectively reduce friction and wear with non-ferrous surfaces (e.g., DLC coatings) [L. 3]. Our approach to address this issue is to focus on the latter aspects, i.e. on novel additives in a form of nano-tubular structures [L. 4]. Using lamellar nanoparticles, such as $\mathrm{MoS}_{2}$, offer a superior lubrication performance due to their low-shear resistance to any applied shear stress [L. 5]. Unfortunately, the tribological performance of these particles is affected by the morphology, structure, and size, along with the large influence of the test conditions [L. 6]. So far, the main conclusion has been that $\mathrm{MoS}_{2}$ in form of multiwall nanotubes (NTs) contain more defects than the IF- $\mathrm{MoS}_{2}$ in the form of pallets and therefore are easily exfoliated. Due to the shearing of the basal planes in nanoparticles, it was recently proposed that such a physical based mechanism can be used for the lubrication of materials with lower chemical reactivity, e.g., DLC coatings [L. 7]. Attempts at lubricating DLC coatings with oils containing $\mathrm{MoS}_{2}$ nanoparticles have been contradictory so far. From one site, it was reported that this combination was not successful [L. 8], while another report showed that, under boundary lubrication conditions, a reduction in friction can reach 50\% compared to the base oil without $\mathrm{MoS}_{2}$ nanoparticles [L. 9]. None of the reports address the upper and lower specimens' wear rate, but mainly report on frictional performance.

Accordingly in this work, the tribological properties were investigated using reciprocating sliding testing machine in a steel-ball-on-coated-disc configuration stressing on wear mechanism appearing on two commercially available coatings: $\mathrm{WC} / \mathrm{C}$ and DLC coating.

\section{MATERIALS AND METHODS}

The tribological tests were performed on a SRV® tribometer (Optimol Instruments Prüftechnik $\mathrm{GmbH}$,
Germany) under reciprocating sliding conditions using a point of contact at the tests parameters given in Table 1. For each coating, the test parameters (contact pressure and test duration) were adjusted individually in order to avoid reaching the $\mathrm{CrN}$ interlayer.

The base material used in tribological tests was AISI 52100 bearing steel with a microstructure formed by fine martensitic iron and disperse micrometre size carbides, which resulted in a hardness of $850 \mathrm{HV} 10$ and a roughness of Ra $0.05 \mu \mathrm{m}$. As the counter-body, AISI 52100 bearing steel balls with a diameter of $10 \mathrm{~mm}$ were used with the same hardness and roughness. Another two series of SRV discs were coated at Oerlicon Balzers with BALINIT@C STAR $(\mathrm{CrN}(1 \mu \mathrm{m})+\mathrm{a}-\mathrm{C}: \mathrm{H}: \mathrm{Me}(\mathrm{WC} / \mathrm{C})$ $(2 \mu \mathrm{m}))$ and BALINIT@ DLC $(\mathrm{CrN}(1 \mu \mathrm{m})+\mathrm{a}-\mathrm{C}: \mathrm{H}$ $(2 \mu \mathrm{m}))$. Both coatings benefit from a hard, durable $1 \mu \mathrm{m}$ thick metal-based inter layer chromium nitride, which supports the superposed carbon coatings (load-bearing capacity). The thickness of both carbon coatings and the interlayer was measured using a Calowear f-my CSM and optical camera VHX1000E Keyence.

The base oil used in this study was NEXBASE® 2008 polyalphaolefine (PAO) with a viscosity of $24.6 \mathrm{~mm}^{2} / \mathrm{s}$ at $40^{\circ} \mathrm{C}$ and $4 \mathrm{~mm}^{2} / \mathrm{s}$ at $100^{\circ} \mathrm{C}$. The $\mathrm{AW}$ additive used in this study is a mixed primary/secondary zinc dialkyl dithiophosphate ZDDP with $99 \%$ purity from Afton chemicals. The $\mathrm{MoS}_{2}$ nanotubes (NTs) investigated in this study were synthesized from $\mathrm{Mo}_{6} \mathrm{~S}_{2} \mathrm{I}_{8}$ nanowires by the procedure reported in [L. 10]. The diameter of the NTs is in the range of $100-150 \mathrm{~nm}$, while their length is up to $3 \mu \mathrm{m}$ as pictured in Figure 1. The walls of the NTs are approx. $10 \mathrm{~nm}$ thick and form dome terminations. The lubricant mixtures containing NTs were homogenized using an ultrasonic processor UP200H (Hielscher - Ultrasound Technology). The selected parameters for $10 \mathrm{ml}$ lubricant blend at the probe tip were $20 \%$ amplitude during $5 \mathrm{~min}$, while the pulse was on and off for 2 seconds, respectively. The AW additives and $\mathrm{MoS}_{2}$ NTs were blended with PAO oil in a $2 \%$ weight concentration. The tribologically investigated samples after the tests were rinsed with Petroleum Ether followed by cleaning in an ultrasonic bath by Isopropanol for 3 minutes (both solvents were HPLC grade). Afterwards, the wear tracks were examined by using a series of surface characterization instruments, including an optical microscope, an optical interferometer, and Scanning Electron Microscopy (SEM) with Energy Dispersive X-ray spectroscopy (EDX).

Optical measurements of the balls wear scare diameter with a precision up to $1 \mu \mathrm{m}$ were realized using a Nikon MM-40/L3FA. The surface topography of the tested samples was evaluated using a Taylor Hobson CCI HD non-contact 3D Optical Profiler. Surface roughness was measured before and after the tests according to ISO 4287. TalyMap Platinum software was used for wear volume analysis. Optical measurements of 
Table 1. Summary of SRV reciprocating sliding tribotest parameters, including a schematic of the experimental set-up

Tabela 1. Warunki badań realizowanych z wykorzystaniem stanowiska SRV pracującego w warunkach ruchu oscylacyjnego wraz ze schematem węzła tarcia

\begin{tabular}{|c|c|c|}
\hline 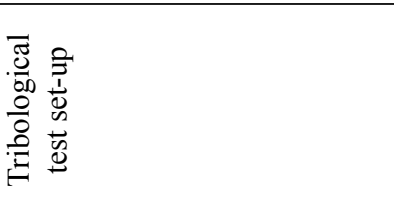 & \multicolumn{2}{|c|}{$\begin{array}{c}\text { SRV® test } \\
\text { Dise Lubricamt } \\
\text { Rerdprosating } \\
\text { silitiog }\end{array}$} \\
\hline Contact conditions & \multicolumn{2}{|c|}{ Point contact at reciprocating sliding } \\
\hline Track length & \multicolumn{2}{|c|}{$1 \mathrm{~mm}$} \\
\hline Tested Disc - Ball materials & $\begin{array}{l}\text { Steel - steel } \\
\text { DLC - steel }\end{array}$ & $\mathrm{WC} / \mathrm{C}$ - steel \\
\hline Speed & $0.1 \mathrm{~m} / \mathrm{s}(50 \mathrm{~Hz})$ & $0.04 \mathrm{~m} / \mathrm{s}(20 \mathrm{~Hz})$ \\
\hline Normal Load & $100 \mathrm{~N}$ & $10 \mathrm{~N}$ \\
\hline Mean contact pressure & $1.46 \mathrm{GPa}$ & $0.68 \mathrm{GPa}$ \\
\hline Test duration & $60 \mathrm{~min}$ & $30 \mathrm{~min}$ \\
\hline Temperature & \multicolumn{2}{|c|}{$40^{\circ} \mathrm{C}$} \\
\hline $\begin{array}{c}\text { Lubricant } \\
\text { blends }\end{array}$ & \multicolumn{2}{|c|}{$\mathrm{PAO}, \mathrm{PAO}+2 \% \mathrm{AW}, \mathrm{PAO}+2 \% \mathrm{NTs}, \mathrm{PAO}+2 \% \mathrm{AW}+2 \% \mathrm{NTs}$} \\
\hline Measured parameters & \multicolumn{2}{|c|}{ Coefficient of friction vs. time, wear rate on discs and balls wear are } \\
\hline
\end{tabular}

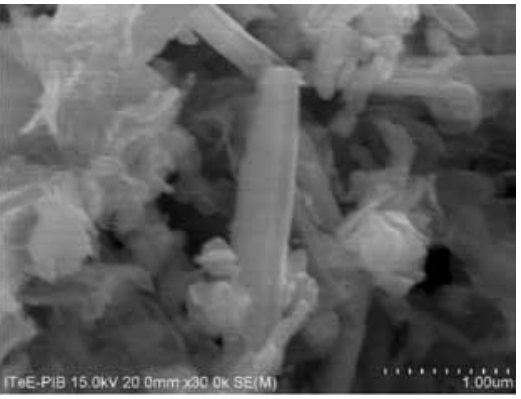

\begin{tabular}{|c|c|}
\hline $\begin{array}{c}\text { Element } \\
\text { Line }\end{array}$ & Atom \% \\
\hline C K & 17.39 \\
\hline O K & 36.02 \\
\hline S K & 27.13 \\
\hline Mo L & 19.45 \\
\hline Total & 100.00 \\
\hline
\end{tabular}

Fig. 1. SEM micrograph and EDX analyses of the $\mathrm{MoS}_{2}$ nanotubes powder, and visible nano-onions released from the nanotubes

Rys. 1. Obraz z mikroskopu skaningowego SEM i analiza chemiczna EDX proszku nanorurek $\mathrm{MoS}_{2}$ oraz uwidocznione nanocebulki uwolnione $\mathrm{z}$ nanorurek

the ball's wear scare diameter with precision up to $1 \mu \mathrm{m}$ were realized using a Nikon MM-40/L3FA.

Scanning electron microscopy micrographs were obtained using a Hitachi SU-70 Analytical Field Emission SEM. It is equipped with a Schottky electron source with ultra-high resolution, and EDS (Energy Dispersive X-ray Spectrometer of the Thermo Scientific), detecting elements from beryllium to uranium. The accelerating voltage range was $0.1-$ $30 \mathrm{kV}$ with an ultra-high resolution observation SE (secondary electron) $1.0 \mathrm{~nm}$ for $15 \mathrm{kV}$, and $1.6 \mathrm{~nm}$ for $1 \mathrm{kV}$. The measurement magnification range was $30 \mathrm{x}-$ $-800000 x$ with a high vacuum in the chamber $10^{-8} \mathrm{~Pa}$. The spectra were acquired at an accelerating voltage of $15.0 \mathrm{kV}$ and a takeoff angle $30.9^{\circ}$ (distance sampledetector $15 \mathrm{~mm}$ ).

\section{RESULTS AND DISCUSSION}

\section{Friction}

In order to understand the effect of lubricants containing $\mathrm{MoS}_{2}$ nanotubes, reciprocating sliding tests were carried out to evaluate the tribological performance of multifunctional coatings working in configuration against the steel pair. The SRV results are presented in a form of frictional scan as a function of time (Fig. 2). It is important to note that the error bars presented on the frictional curves represent the average of three repetitions, and it can be stated that reproducibility of the results was very good for all test conditions. As expected and reported previously by many researches [L. 11], strong friction reduction (by $45 \%$ compare to the base oil) is observed for the lubricant blend containing $\mathrm{MoS}_{2}$ NTs in steel-steel material configuration (Fig. 2a). In the DLC-steel material combination, the effect of the lubricant containing $\mathrm{MoS}_{2}$ NTs is much lower, reaching $24 \%$ (Fig. 2b). For the material configuration WC/Csteel, the friction reduction between $\mathrm{PAO}$ and $\mathrm{PAO}+\mathrm{NTs}$ is only $10 \%$ (Fig. 2 c).

The addition of AW additive to the PAO influenced the base oil performance in terms of friction the strongest in the steel-steel test configuration (Fig. 2a). In the DLC-steel contact, there is no effect (Fig. 2b), and in the $\mathrm{WC} / \mathrm{C}-$ steel configuration, a transition from higher friction in first $10 \mathrm{~min}$ of the test to the lower friction after that time was observed (Fig. 2c). The best results in term of friction for all materials configurations were observed for the PAO+AW+NTs lubricating blend. Friction reduction was $56 \%$ in steel-steel contact, $34 \%$ in DLC-steel, and $27 \%$ in $\mathrm{WC} / \mathrm{C}$-steel-disc-ball 
material arrangement. The synergistic efect between $\mathrm{MoS}_{2}$ NTs and ZDDP additive could also be highlighted within the present work and is in agreement with results reported in literature [L. 12].

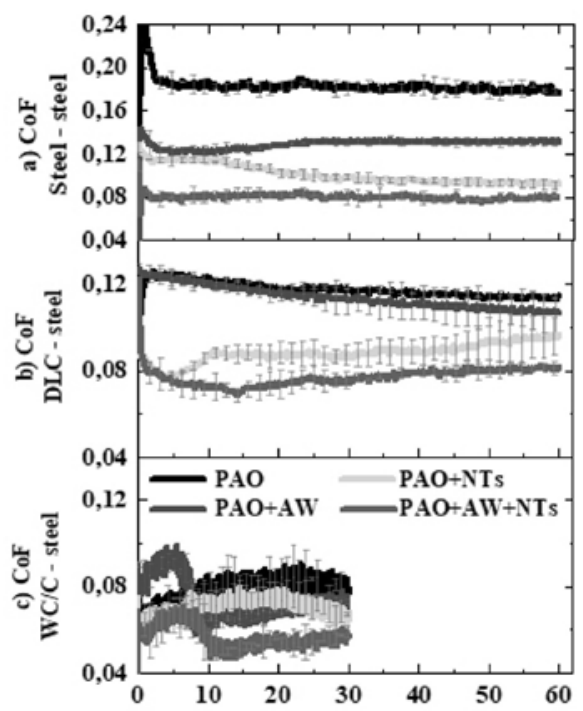

Fig. 2. SRV tests results represented with friction curves including error bars distribution over the curve for following material configurations a) steel steel, b) DLC-steel, c) WC/C-steel

Rys. 2. Przebiegi współczynnika tarcia wraz z zaznaczonymi rozrzutami dla skojarzeń: a) stal-stal b) DLC-stal c) $\mathrm{WC} / \mathrm{C}-$ stal

The reason is formation of nanosheets within the tribofilm formed on bare steel surface (iron oxide), and within/on the top layer of ZDDP tribofilm formed on the steel surface with the preformed ZDDP film. The mechanism on coated surfaces is not yet revealed.

\section{Wear}

Specific wear rates on the disc were calculated according the Archard's formula: $=\frac{V}{F \times S}$, where $V$ is the wear volume $\left(\mu \mathrm{m}^{3}\right), F$ is the normal load $(\mathrm{N})$, and $S$ is the sliding distance $(\mathrm{m})$. The wear areas of the balls were calculated from the formula $\frac{\pi \times d 1 \times d 2}{4}$, where $d_{1}$ is the horizontal wear diameter and $d_{2}$ is the vertical wear diameter.

As shown in Fig. 3, the most sensitive to wearing is the $\mathrm{WC} / \mathrm{C}$ coating in reciprocating sliding point contact. Due to this fact, the parameters of the test were reduced to the minimum, where the interactions of the lubricant blends and the $\mathrm{WC} / \mathrm{C}$ coating were strongest, without reaching the $\mathrm{CrN}$ interlayer.

As shown in Fig. 3a on the steel-steel surfaces, the disc and the ball wear with the additive-free PAO was the highest, which was reduced when NTs were used. The strongest reduction of wear rate was obtained for $\mathrm{PAO}+\mathrm{AW}$ and $\mathrm{PAO}+\mathrm{AW}+\mathrm{NTs}$, which is not surprising, since ZDDP forms thick tribofilms that prevent surfaces from wearing. It is interesting to note that, as in frictional

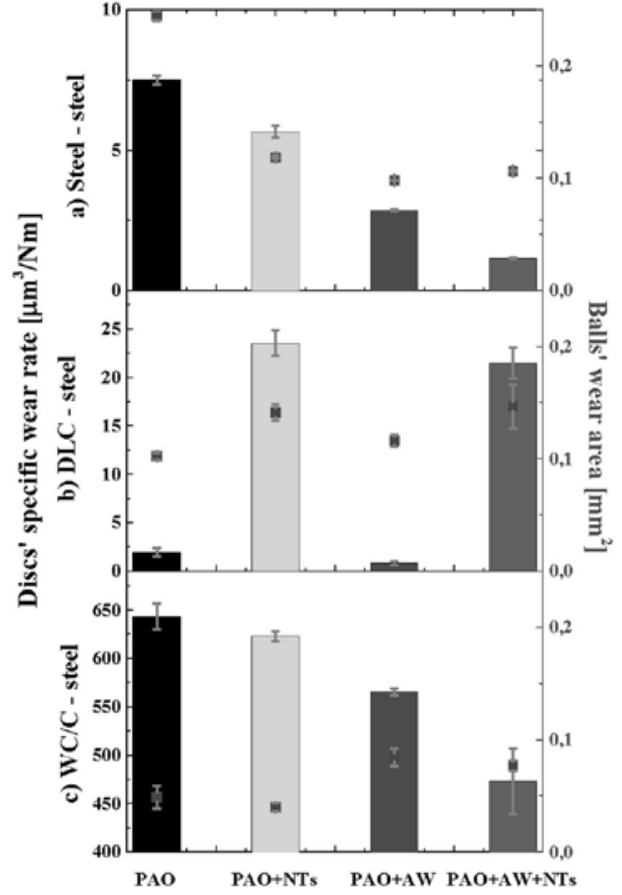

Fig. 3. Disc and ball wear of the different tested pairs as function of the lubricant mixture

Rys. 3. Parametry zużycia na dysku oraz na kulce dla badanych konfiguracji materiałowych i kompozycji smarowych

results, the best synergy on the steel surface is observed for the $\mathrm{PAO}+\mathrm{AW}+\mathrm{NTs}$ lubricant blend. In this case, the original anti-wear properties of the formed ZDDP tribofilm are further improved, which suggest that NTs were incorporated within and deposited on the top of ZDDP layer building even thicker additives and the tribofilm. Similar effects of the additives were observed on the $\mathrm{WC} / \mathrm{C}-$ steel tested materials (Fig. 3c).

However, on the DLC-steel material configuration shown in Fig. 3b, a reverse action of the lubricant blend containing NTs can be observed. Only when $\mathrm{MoS}_{2}$ NTs are used either accompanied with AW or not, extensive wear is visible on the DLC surface, suggesting that NTs are scrubbing this coating (mechanical action) or there exist a strong chemical reactivity between a-C:H coating and $\mathrm{MoS}_{2}$ NTs based additives (tribo-chemical action. The AW additive represented by ZDDP, as on steel surfaces, forms thick tribofilms that prevent surfaces from wearing. Nonetheless, adding NTs to the PAO+AW blend diminish the effectiveness of ZDDP.

\section{Surface Topography}

Optical measurements of the balls wear scare diameter with precision up to $1 \mu \mathrm{m}$ were realized using a Nikon MM-40/ L3FA. Wear track topography of the tested samples was evaluated using a Taylor Hobson CCI HD non-contact 3D Optical Profiler. 3D images of selected discs after SRV test with PAO and PAO+NTs lubricating blends are presented in Fig. 4. Height parameters of the surface within the wear track were calculated according ISO 25178, and they are given below the topography images. 


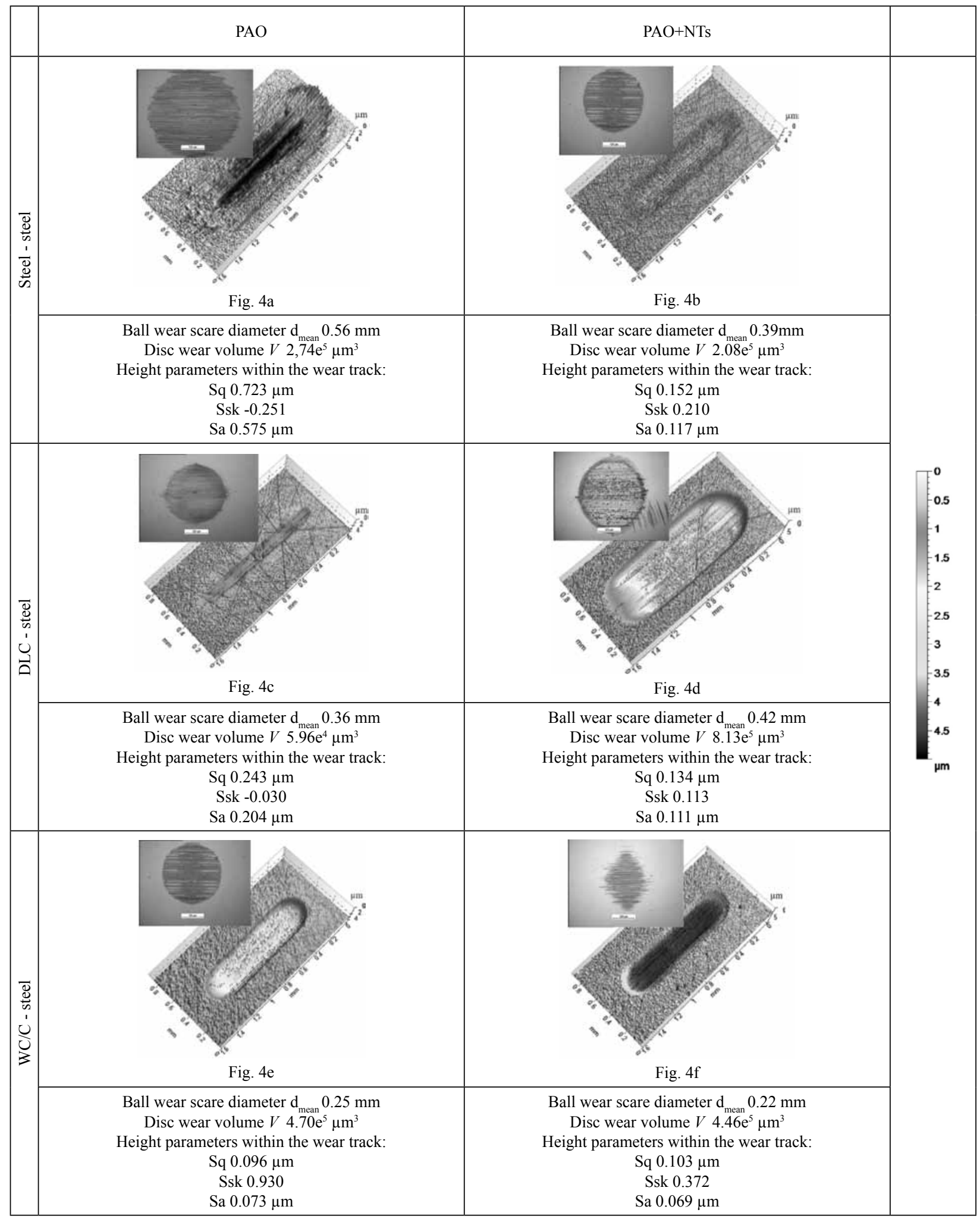

Fig. 4. Optical microscopy images of the wear scare on the tested steel balls and wear tracks topography of the tested discs for the following material and lubricant combination a) steel-steel in PAO base oil, b) steel-steel in PAO+NTs blend, c) DLC-steel in PAO base oil, d) DLC-steel in PAO+NTs blend, e) WC/C-steel in PAO base oil, f) WC/C-steel in PAO+NTs blend

Rys. 4. Obrazy z mikroskopu optycznego śladów zużycia na kulkach oraz topografie śladów zużycia na dyskach dla następujących konfiguracji materiałowych i smarowych a) stal-stal z olejem bazowym PAO, b) stal-stal z kompozycją olejową PAO+NTs, c) DLC-stal z olejem bazowym PAO, d) DLC-stal z kompozycją olejową PAO+NTs, e) WC/C z olejem bazowym PAO, f) WC/C-stal z kompozycją olejową PAO+NTs 
Roughness parameter Sa within the wear track, which is usually severely damaged, do not fit for purpose of assessing surface finish. From this point of view, a better parameter describing the SRV wear track damage is skewness Ssk or kurtosis Sq. If the ratio of peaks to valleys is similar, the distribution is symmetric, then the mean is equal to the median, and the distribution has zero skewness. The direction of skew depends on whether the bulk of the material is above the mean line (negative skew) or below it (positive skew). The porous, spiky, corroded, or transferred material on the wear track has a large value of skew, while the surface with sharp groves or pits will have a negative skew. On the other hand, kurtosis provides a measure of the sharpness of the surface, with a spiky surface having a high kurtosis value and a bumpy surface having a low Kurtosis value [L. 13].

From Figs. $4 \mathbf{a}$ and $\mathbf{4 b}$, it is obvious that the damage on the steel ball and the steel disc is highest for the SRV tests performed with pure PAO base oil. The skewness on the steel surface after tests with PAO oil is negative, meaning that the surface has lots of sharp groves and craters, while the kurtosis is high saying that it has lots of spikes. On the steel surface after SRV tests with PAO+NTs blend, the results of kurtosis and skewness are above zero and very low, meaning a fine and smooth surface. The presence of the NTs in the PAO oil reduces the wear volume and ball wear scare diameter, as well as roughness within the wear track zone on the disc possibly due to the tribofilm formation, which will be proved further by SEM/EDX analyses. The situation is completely different when we focus on Figs. $\mathbf{4 c}$ and $\mathbf{4 d}$, where the tests were performed with steel ball on DLC coated disc. The disc wear volume for the tests performed using the PAO+NTs blend is one order of magnitude higher compare to the PAO base oil.
Nevertheless, the balls wear scare diameter is comparable for both oils. This result means that, although PAO+NTs gave very low friction (Fig. 2b), there must be strong chemical reactivity between the DLC coating and $\mathrm{MoS}_{2}$ NTs causing wide wear on the DLC coated disc. Regarding the roughness of the DLC discs' surface within the wear track, the one after tests with PAO (Fig. 4c) is rougher, having higher value of kurtosis and slightly below zero skewness due to the few pits in the middle on the wear zone (starting point of the DLC coating destruction). The DLC discs' surface within the wear track after tests with $\mathrm{PAO}+\mathrm{NTs}$ is very smooth either due to the patchy tribo-film formation and/or approaching the smooth $\mathrm{CrN}$ interlayer. Both scenario are proved further by SEM/EDX analyses.

Figures $\mathbf{4 e}$ and $\mathbf{4 f}$ indicate that the $\mathrm{WC} / \mathrm{C}$ coating is least affected by the NTs presence in the PAO oil blend. The differences of the discs wear volume, roughness, and wear scare diameter of the balls are negligible.

\section{Surface Analytics}

The morphology of the surfaces before and after the SRV tribological tests were inspected using Hitachi SU-70 Analytical Field Emission SEM, equipped with a Schottky electron source with ultra-high resolution, and EDS (Energy Dispersive X-ray Spectrometer of the Thermo Scientific), detecting elements from beryllium to uranium.

As the first step, the disc's surfaces were analysed before tribological tests in order to reveal the morphology of the AISI 52100 bearing steel substrates before and after the coating deposition (Fig. 5). The result presented in Fig. 5a, shows the steel disc's bare surface before the deposition of the coating and before any tribological tests. Figure 5b presents a SEM micrograph of the

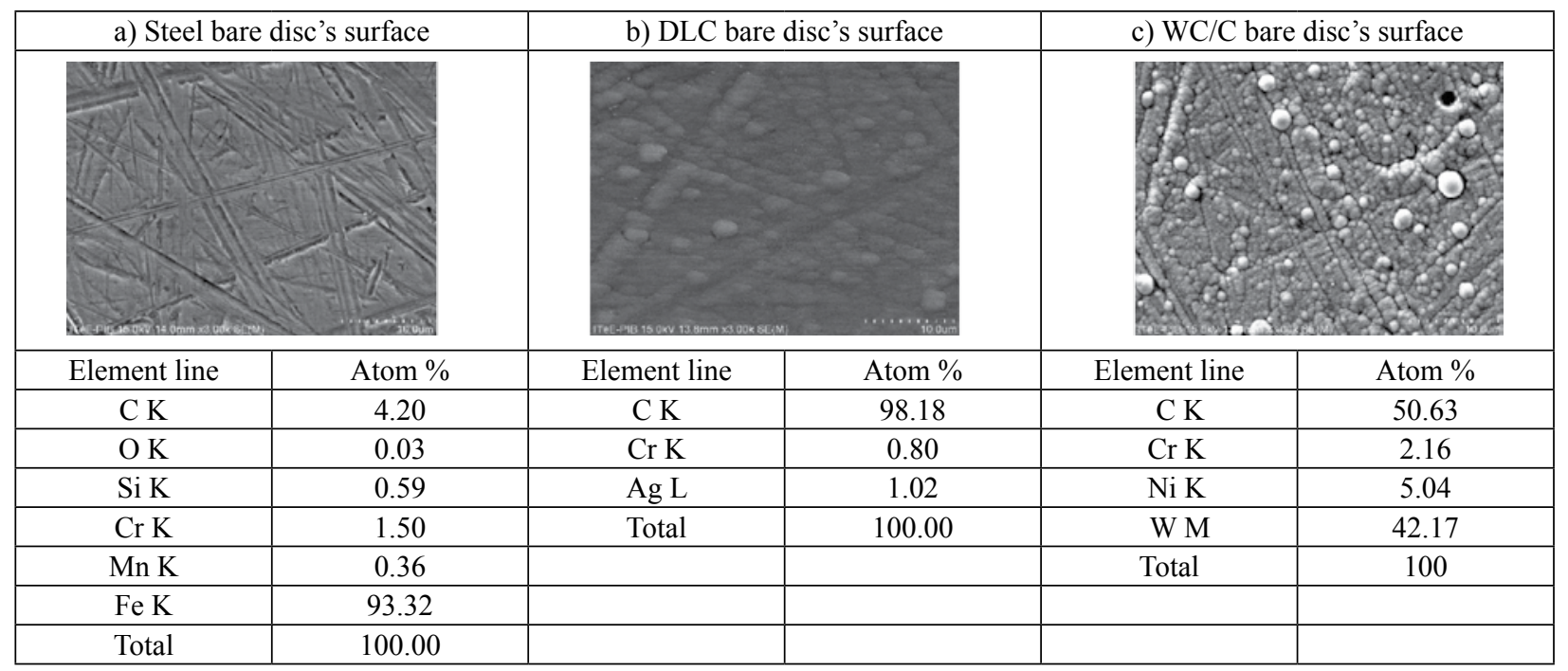

Fig. 5. SEM micrographs of the disc's surfaces before tribological tests a) bare steel surface before the deposition of the coating b) freshly deposited a-C:H, c) freshly deposited a-C:H:W

Rys. 5. Obrazy z mikroskopu skaningowego SEM powierzchni dysków przed badaniami tribologicznymi: a) surowa powierzchnia stalowa przed osadzeniem powłoki, b) powierzchnia naniesionej powłoki a-C:H, c) powierzchnia naniesionej powłoki a-C:H:W 
deposited coating BALINIT@ DLC (CrN $(1 \mu \mathrm{m})+$ a-C:H $(2 \mu \mathrm{m}))$, and Fig. 5c with the coating BALINIT@ C STAR $(\mathrm{CrN}(1 \mu \mathrm{m})+\mathrm{a}-\mathrm{C}: \mathrm{H}: \mathrm{Me}(\mathrm{WC} / \mathrm{C})(2 \mu \mathrm{m}))$.

The formation of the tribofilm when using nanotubes is assessed by comparing surface morphology using SEM-EDX shown in Fig. 6. Following Fig. 6a and the chemical surface analyses, it can be noticed that, typical for steel-steel contacts lubricated with additive-free PAO base oil, there is a rough wear track with many cracks, fractures, and breaches. The clearly high presence of iron oxides and a relatively high amount of $\mathrm{Cr}$ and $\mathrm{Ni}$ indicate deep damage of 100Cr6 steel material. This state of the surface is not surprising when we go back to the frictional scans presented in Fig. 2a, showing that the base PAO oil friction was very high, reaching the test value of 0.25 in the first five minutes (lubricant starvation), where the deepest craters were formed, and there was a stabilizing in a later stage of the test to the value of 0.2. Whenever base PAO oil is blended with an additives (AW or NTs), both friction is much lower (Fig. 2a) and the quality of the surface is much better, as shown in Fig. $\mathbf{4 b}$ and Fig 6b. The roughness value within the wear track drop from $0.58 \mu \mathrm{m}$ after test with PAO down to 0.12 after tests with PAO+NTs, and the surface morphology shown in Fig. $6 \mathbf{b}$ is fine with visible typical patches of the tribofilm formed from NTs as shown as well by Tomala et al. [L. 12]. The formation of the $\mathrm{MoS}_{2}$ NTs derived tribolayer on the steel surface shown in Fig. $\mathbf{6 b}$ is confirmed with EDX analyses showing $16.8 \%$ of Molybdenum and $8.7 \%$ of Sulphur as well as $20.4 \%$ of Oxygen and $48.7 \%$ Fe. After the tests with pure PAO oil, the amount of iron was almost $70 \%$, confirming the thicker coverage of the steel surface after tests with PAO+NTs. Relatively high amounts of oxygen on the steel disc surface after the tests with PAO+NTs result from the presence of $\mathrm{MoO} 3$ within the NTs, as confirmed by EDX analyses of the NTs powder shown in Fig. 1.

Regarding the SRV reciprocating sliding tribological tests in the DLC (a-C:H)-steel configuration with the base oil PAO, the coefficient of friction was 0.12 (Fig. 2b) and the specific wear rate on the disc was $1.95 \pm 0.41 \mu \mathrm{m}^{3} /$ $\mathrm{Nm}$ (Fig. 3b). The presence of AW additive in the PAO blend resulted in negligible changes in friction (Fig. 2b), but the specific wear rate on the disc was $0.82 \pm 0,18 \mu \mathrm{m}^{3} /$ $\mathrm{Nm}$ (Fig. 3b). The presence of NTs either in the PAO oil blend or in the PAO+AW blend resulted in friction reduction down to 0.08 (Fig. 2b), but the specific wear rate on the disc was above $20 \mu \mathrm{m}^{3} / \mathrm{Nm}$ (Fig. 3b). These results clearly indicate strong chemical reactivity during the tribological tests between the $\mathrm{MoS}_{2}$ NTs and the hydrogenated amorphous carbon coating, especially knowing that the wear scare diameter of the ball did not change too much (Figs. 4c and d). SEM/ EDX performed on the DLC discs' wear track shown in Figs. 6c and d indicate that, after tests with PAO, the DLC coating is still present on the wear track (a darker colour indicates smaller atomic nucleus, in our case it is light carbon) and after the tests with PAO+NTs, the DLC coating is completely gone (brighter colours indicate

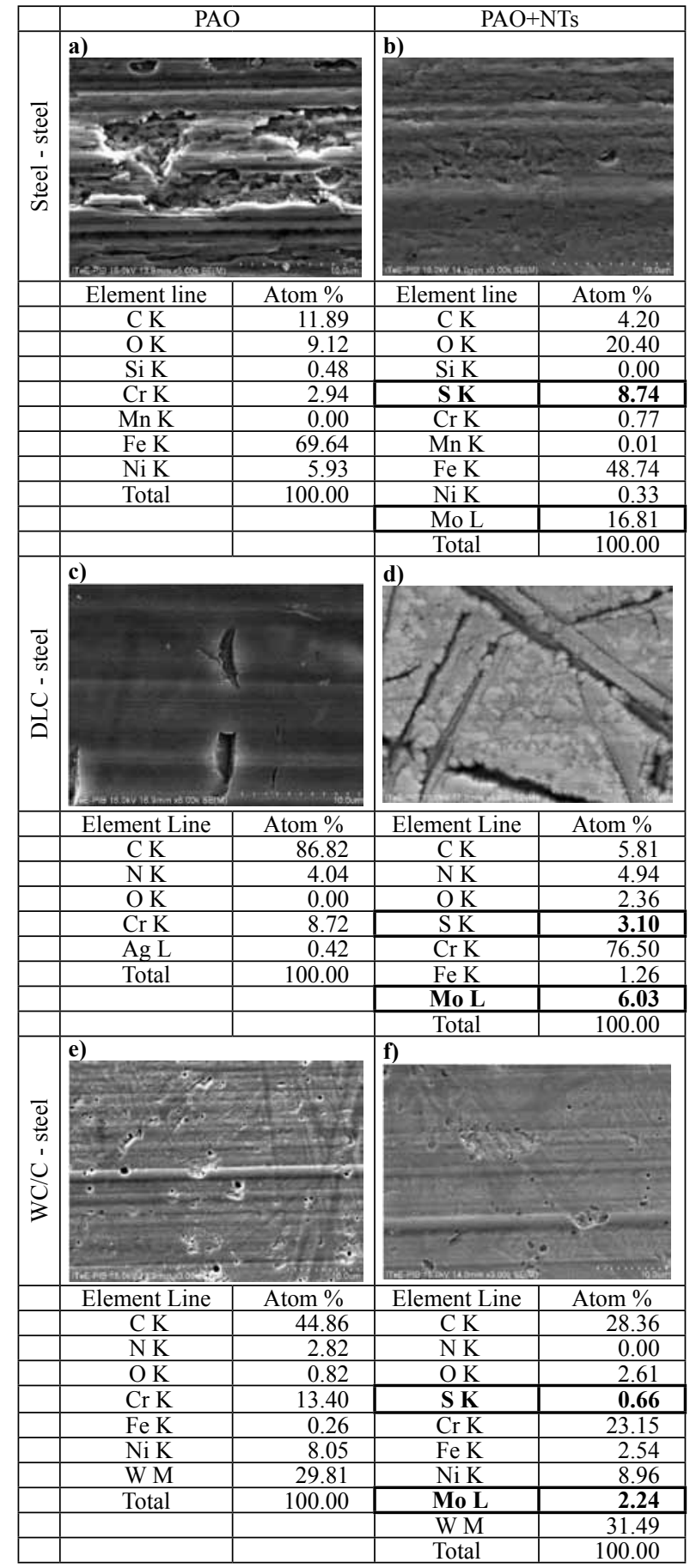

Fig. 6. SEM micrographs and EDX surface analyses of the disc's wear tracks for the following material and lubricant combination a) steel-steel in PAO base oil, b) steel-steel in PAO+NTs blend, c) DLC-steel in PAO base oil, d) DLC-steel in PAO+NTs blend, e) $\mathrm{WC} / \mathrm{C}$-steel in PAO base oil, $\mathrm{f}$ ) $\mathrm{WC} / \mathrm{C}$-steel in PAO+NTs blend

Rys. 6. Obrazy z mikroskopu skaningowego SEM wraz z analizą chemiczną EDX śladów zużycia na dyskach dla następujących konfiguracji materiałowych i smarowych: a) stal-stal z olejem bazowym PAO, b) stal-stal z kompozycją olejową PAO+NTs, c) DLC-stal z olejem bazowym PAO, d) DLC-stal z kompozycją olejową PAO+NTs, e) WC/C z olejem bazowym PAO, f) WC/C-stal z kompozycją olejową PAO+NTs 
a higher atomic number, in our case, it is heavy $\mathrm{CrN}$ ). EDX presented in the tables below proved the above assumption. After tests with PAO shown in Fig. 6c, there is a high atomic concentration of $\mathrm{C}$ of $87 \%$, with a low concentration of $\mathrm{Cr}$ of only $9 \%$. After the SRV tests with $\mathrm{PAO}+\mathrm{NTs}$, the EDX spectrum analyses presented in Fig. $6 \mathrm{~d}$ showed a low content of $\mathrm{C}$, below $6 \%$, and high content of $\mathrm{Cr}$ of $77 \%$, with slight traces of $\mathrm{Fe}(1.3 \%)$ from the steel substrate underneath the $\mathrm{CrN}$ interlayer.

Nonetheless, the strong chemical reactivity between the a-C:H coating and $\mathrm{MoS}_{2}$ NTs causing extensive wear and removal of the DLC coating left a footprint on the $\mathrm{CrN}$ interlayer surface in a form of smeared patches of $\mathrm{MoS}_{2}$, which are visible in Fig. 6d as cloudy structures. The presence of exfoliated NTs on the surface is not as high as on the steel disc wear track, where the entire wear track surface was covered with the tribofilm derived from $\mathrm{MoS}_{2}$ NTs (Fig. 6b).

The SRV reciprocating sliding tribological tests in the WC/C (a-C:H:W)-steel configuration with the base oil PAO compared to the PAO+NTs blend resulted in a negligible reduction of the $\mathrm{CoF}$ (from $0.079 \pm 0,005$ down to $0.071 \pm 0,004$ as shown in Fig. 2c), as well as the specific wear rate on the disc from $643.18 \pm 13.25$ $\mu \mathrm{m}^{3} / \mathrm{Nm}$ down to $622.67 \pm 5.1 \mu \mathrm{m}^{3} / \mathrm{Nm}$ in Fig. 3c. The wear track surface morphologies illustrated with SEM in Figs. 6e and $\mathbf{f}$ are also very similar, with slightly more defects on the first surface after tests with PAO. The EXD spectrum analyses presented in tables under Fig. 6e and $\mathrm{f}$ showed some small differences in $\mathrm{C}$ and $\mathrm{Cr}$ composition that could indicate that the $\mathrm{WC} / \mathrm{C}$ coating is slightly thinner after tests with PAO+NTs. It is worth noticing that a small detectable signal from Mo and $\mathrm{S}$, indicating the presence of NTs, is not visible in a form of tribofilm, but rather some NTs hidden in dark craters after WC particles dropped out from the coating.

\section{CONCLUSIONS}

The purpose of this work was to reveal the interaction mechanism of $\mathrm{MoS}_{2}$ based nanotubes and classical AW additives with steel, DLC, and $\mathrm{WC} / \mathrm{C}$ coated elements in lubricated reciprocating sliding tribo-contact.

The overall conclusion is that the $\mathrm{MoS}_{2}$ NTs are the most effective in friction reduction, both in steel-steel and coating-steel test configuration. In respect to wear interaction mechanism of MoS2 and NTs, it depends on the type of the coating. For the $\mathrm{WC} / \mathrm{C}$ coating, the $\mathrm{MoS}_{2}$ nanotubes reduce wear significantly, even more when accompanied by an AW additive. On the other hand, for the DLC coating, extensive wear and complete removal of the coating was observed.

Detailed conclusions are as follows:

- In terms of friction, the best results were observed for $\mathrm{PAO}+\mathrm{AW}+\mathrm{NTs}$ lubricating blend for all material configurations, suggesting a strong synergetic effect between the ZDDP additive and $\mathrm{MoS}_{2}$ nanotubes.

- Steel surfaces and DLC coatings are the most sensitive to the tribological interaction of the additives, while the $\mathrm{WC} / \mathrm{C}$ coating seems to be least sensitive to the selected lubricant additives.

- In terms of wear, the discs' specific wear rate on steel and $\mathrm{WC} / \mathrm{C}$ is lowest for $\mathrm{PAO}+\mathrm{AW}+\mathrm{NTs}$ lubricating blend, except for DLC coatings.

- Strong chemical reactivity between the a-C:H coating and $\mathrm{MoS}_{2}$ NTs based additives cause extensive wear on the DLC coating, down to $\mathrm{CrN}$ interlayer, where smeared patches of exfoliated $\mathrm{MoS}_{2}$ NTs were detected.

The obtained results suggest that, for modern coating materials, tribological interaction with novel oil additives can be not only synergetic but also antagonistic.

\section{ACKNOWLEDGEMENTS}

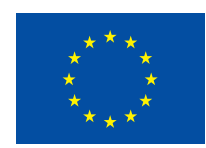

This project has received funding from the European Union's Horizon 2020 research and innovation programme under the Marie Skłodowska-Curie grant agreement No 665778. The author A. Tomala acknowledges the POLONEZ project by National Science Centre, Poland, under fellowship registration number 2015/19/P/ST8/02597.

This work was also partially funded by the Austrian COMET Programme (Project K2 XTribology. No. 849109).

\section{REFERENCES}

1. Holmberg K., Ronkainen H., Laukkanen A., Wallin K.: Friction and wear of coated surfaces - scales, modelling and simulation of tribomechanisms, Surf. Coatings Technol., 2007, vol. 202, no. 4-7, pp. 1034-1049.

2. Michalczewski R., Piekoszewski W., Szczerek M., Tuszynski W., Antonov M.: The Rolling Contact Fatigue of PVD Coated Spur Gears, in Engineering Materials and Tribology, 2013, vol. 527, pp. 77-82.

3. Kalin M., Velkavrh I., Vižintin J., Ožbolt L.: Review of boundary lubrication mechanisms of DLC coatings used in mechanical applications, Meccanica, 2008, vol. 43, no. 6, pp. 623-637.

4. Tenne R., Margulis L., Genut M., Hodes G.: Polyhedral and cylindrical structures of tungsten disulphide, Nature, Dec. 1992, vol. 360, no. 6403, pp. 444-446. 
5. Martin J.M., Donnet C., Le Mogne T., Epicier T.: Superlubricity of molybdenum disulphide, Phys. Rev. B, Oct. 1993, vol. 48, no. 14, pp. 10583-10586.

6. Lahouij I., Vacher B., Martin J.M., Dassenoy F.: IF-MoS 2 based lubricants: Influence of size, shape and crystal structure, Wear, 2012, vol. 296, pp. 558-567.

7. Kogovšek J., Remškar M., Kalin M.: Lubrication of DLC-coated surfaces with $\mathrm{MoS}_{2}$ nanotubes in all lubrication regimes: Surface roughness and running-in effects, Wear, 2013, vol. 303, no. 1-2, pp. 361-370.

8. Tannous J., Dassenoy F., Lahouij I., Le Mogne T., Vacher B., Bruhács A., Tremel W.: Understanding the tribochemical mechanisms of IF-MoS 2 nanoparticles under boundary lubrication, Tribol. Lett., 2011, vol. 41, no. 1, pp. 55-64.

9. Kalin M., Kogovšek J., Kovač J., Remškar M.: The Formation of Tribofilms of MoS2 Nanotubes on Steel and DLC-Coated Surfaces, Tribol. Lett., 2014, vol. 55, no. 3, pp. 381-391.

10. Remškar M., Viršek M., Mrzel A.: The $\mathrm{MoS}_{2}$ nanotube hybrids,Appl. Phys. Lett., 2009, vol. 95, no. 13, pp. 2-4.

11. Tomala A., Ripoll M.R., Gabler C., Remškar M., Kalin M.: Interactions between MoS nanotubes and conventional additives in model oils, Tribol. Int., 2017, vol. 110.

12. Tomala A., Vengudusamy B., Rodríguez M. Ripoll, Naveira A. Suarez, Remškar M., Rosentsveig R.: Interaction between selected $\mathrm{MoS}_{2}$ nanoparticles and ZDDP tribofilms Tribol. Lett., 2015, vol. 59, no. 1.

13. Leach R.: Characterisation of areal surface texture, Springer-Verlag Berlin Heidelberg, 2013. 